Всероссийской научно-практической конференции с международным участием по спортивной науке: «Подготовка спортивного резерва» 1-2 декабря 2020г. (статья) ГКУ «ЦСТиСК» Москомспорта, ФЦПСР Минспорта, в формате PDF - М.: ГКУ «ЦСТиСК» Москомспорта, 2020. - 569 страниц. ISBN 978-5-99052529-0, c. 84-87.

3. Ткачук М.Г., Дюсенова А.А. Морфологические признаки полового диморфизма у женщин-спортсменок: монография: НГУ им. П.Ф.Лесгафта. СПБ, 2009.- 112 с.

4. Krzykała Magdalena, Karpowicz Małgorzata, Strzelczyk Ryszard, Pluta Beata, Podciechowska Karolina, Investigation, Karpowicz Krzysztof; Loenneke, Jeremy P. (2020). Morphological asymmetry, sex and dominant somatotype among Polish youth. PLOS ONE, 15(9), e0238706-. doi:10.1371/journal.pone.0238706

\title{
Елькина Н.А., Осипова А.А. \\ Адаптированность генеративной сферы Tripolium pannonicum (астры солончаковой) к условиям обитания на приливно-отливной зоне побережья Белого моря
}

Петрозаводский государственный университет (Россия, Петрозаводск)

doi: 10.18411/trnio-10-2021-105

\section{Аннотация}

Астра солончаковая - типичный галофит, обитающий на приливно-отливной зоне побережья Белого моря. Нами исследованы морфологические характеристики пыльцы астры солончаковой, проведена оценка количества нормально сформированной пыльцы и различных форм тератов, изучена адаптированность астры к генеративному размножению на разных зонах литорали.

Ключевые слова: пыльцевое зерно, адаптивный потенциал, тератоморфы, Белое море.

\section{Abstract}

Sea aster is a typical halophyte of the intertidal zone of the White Sea coast. We measured the morphological characteristics of the pollen of the sea aster, assessed the amount of normally formed pollen and various forms of terata. Adaptation of the aster to generative reproduction in different zones of the littoral was studied.

Keywords: pollen grain, adaptive potential, teratomorphs, White Sea.

Большие экономические перспективы развития Арктического региона диктуют необходимость проведения исследований биоты для оценки уязвимости экосистем и их компонентов и возможных реакций на различные воздействия. Организмы (в том числе растения), обитающие на литорали, в разной степени адаптированы к обитанию в постоянно изменяющихся условиях приливно-отливной зоны. Часть Северного Ледовитого океана Белое море - удобный для проведения мониторинговых исследований водоем. На береговой зоне, в месте контактов различных сред (водная, воздушная, почвенная) наиболее активно происходят процессы видообразования и отмечается большая продуктивная активность. Таким образом, по состоянию небольшой модельной территории можно оценивать благополучие бо́льших частей моря или океана.

Особенности биологии типичного представителя прибрежной зоны Белого моря Астры солончаковой Tripolium pannonicum (Jacg.) Dobrocz. Subsp. tripolium (L.) Greuter для оценки состояния ценопопуляций на различных субстратах по градиенту суточной динамики заливания исследованы в ряде работ $[3,6,7]$. Однако эколого-биологические свойства вида, позволяющие успешно реализовывать жизненный цикл и взаимодействовать с факторами абиотической среды в настоящее время изучены недостаточно. 
Целью нашего исследования было изучение качества пыльцы астры солончаковой ( $T$. pannonicum) на разных зонах литорали по морфологическим характеристикам и оценка адаптированности генеративной сферы к стрессовым условиям обитания.

Астра солончаковая - двулетнее травянистое растение высотой от 15 до $80 \mathrm{~cm}$. Стебель прямостоячий, полый, бороздчатый с мясистыми листьями ланцетной формы. Соцветия корзинки диаметром 10-15 мм в густом метельчатом соцветии. Краевые цветки соцветий - ложноязычковые, сиренево-розоватые, центральные цветки трубчатые, желтые. Плоды - голые семянки. Цветение растения продолжается с июня до августа.

А. солончаковая предпочитает илистые местообитания и часто встречается в зоне ежедневного заливания морскими водами на глинистых или каменистых осушках побережья Белого моря. Установлено, что с повышением уровня воды количество нераскрывшихся корзинок на растении снижается, что может свидетельствовать о наличии определенной адаптированности растений к гидрофилии.

По литературным данным нормально развитые пыльцевые зерна астры солончаковой сфероидальной формы. Имеют три длинные борозды с погруженными в них округлыми порами. С полюсов пыльцевое зерно имеет трехлопастное очертание. Средний диаметр пыльцевого зерна составляет 25-30 мкм. Пыльца покрыта толстой экзиной с крупношиповатой скульптурой. Шипы равновеликие, с коническим основанием и заостренной верхушкой [7].

Соцветия астры солончаковой были собраны в июле 2020 года недалеко от г. Беломорск, в окрестностях пос. Растьнаволок Беломорского района Республики Карелия (64²2'81"N, 3593'14"Е). Для сбора пыльцевого материала была заложена трансекта длиной 300 м по градиенту заливания в направлении от нижней литорали до супралиторали. На трансекте были выделены три зоны, различные по типу субстрата и флористическому составу.

Пробы пыльцы астры взяты во всех зонах трансекты: 1 зона - ПП1 у уреза воды (нижняя литораль), 2 зона - ПП2 центральная часть трансекты (средняя литораль), 3 зона ПП3 у коренного берега (верхняя литораль) и зафиксированы в 70\% спирте. Морфология пыльцы изучена стандартным ацетокарминовым методом [5], который дает возможность описать морфологические структуры пыльцевых зерен, как нормально развитых, так и различных форм тератов и дать оценку качества пыльцы. Для каждой зоны трансекты было исследовано не менее 500 пыльцевых зерен астры солончаковой в трех последовательностях.

Пыльца, имеющая нормальное морфологическое строение состоит из вегетативной клетки с равномерно зернистой и окрашенной в темно-розовый или карминово-красный цвет цитоплазмой, ядра вегетативной клетки и генеративной клетки. Тератоморфная (аномальная, дефектная) пыльца имеет непрокрашенную или неравномерно окрашенную цитоплазму вегетативной клетки или представлена сморщенными пыльцевыми зернами, пыльцой без содержимого или с видимыми признаками редукции цитоплазмы и др.

Астра солончаковая была обнаружена во всех зонах трансекты. Результаты исследования показывали, что наибольший процент пыльцы с нормальной морфологией $89,7 \%$ имеют растения, произрастающие на ПП2 в центральной части литорали. Наименьшее количество пыльцевых зерен с нормальным морфологическим строением - 82,7\% оказалось у растений с ПП1. Данная зона расположена ближе всего к урезу воды и характеризуется максимальным влиянием приливно-отливной волны (табл. 1).

Во всех пробах была обнаружена пыльца с различными дефектами развития. Чаще всего аномалии строения пыльцы астры солончаковой связаны с уменьшением размеров пыльцевого зерна. Так, в пробах обнаружены пыльцевые зерна диаметром 12-15 мкм $(3,8-$ 9,8\%), что вдвое меньше среднестатистической нормы. Пыльца гигантских размеров (не менее 50 мкм) встречается гораздо реже (0,7-1,2\%). Такие пыльцевые зерна не имеют видимых признаков аномалий развития цитоплазмы и экзины. 
Анализ морфологического строения пыльщевыхх зерен (п.з.) Tripolium pannonicum (\%)

\begin{tabular}{|c|c|c|c|c|c|c|c|}
\hline \multirow[b]{2}{*}{ 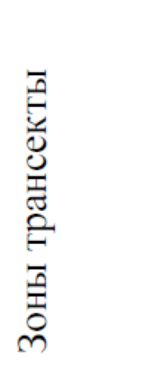 } & \multicolumn{7}{|c|}{ Варианты морфологического строения пыльцы: } \\
\hline & 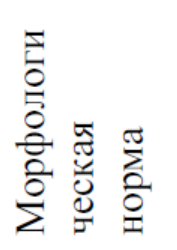 & 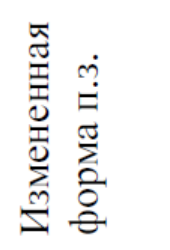 & 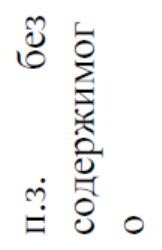 & 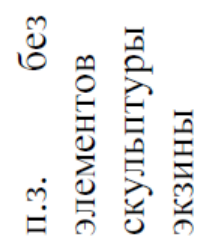 & 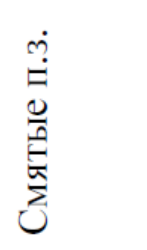 & 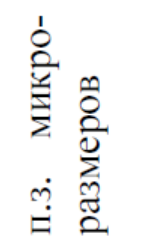 & 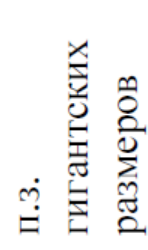 \\
\hline зона 1 & $82,7 \pm 6,1$ & $1,9 \pm 1,0$ & $3,0 \pm 4,4$ & $0,9 \pm 0,7$ & $0,9 \pm 0,5$ & $9,8 \pm 3,4$ & $0,7 \pm 0,4$ \\
\hline зона 2 & $89,7 \pm 1,2$ & $3,2 \pm 0,4$ & $0,5 \pm 0,5$ & $0,7 \pm 0,2$ & $0,5 \pm 0,2$ & $3,6 \pm 1,7$ & $0,7 \pm 0,2$ \\
\hline зона 3 & $86,6 \pm 4,3$ & $1,4 \pm 0,4$ & $0,5 \pm 0,5$ & $5,4 \pm 4,9$ & $0,7 \pm 0,6$ & $3,8 \pm 2,9$ & $1,2 \pm 0,9$ \\
\hline
\end{tabular}

Во всех пробах зафиксированы аномалии развития скульптуры экзины пыльцы астры солончаковой $(0,7-5,4 \%)$. Пыльца стандартных размеров, однако шипы на поверхности экзины неравномерно сглажены или совсем отсутствуют. Цитоплазма вегетативной клетки выглядит пятнистой. Больше всего такой пыльцы в ППЗ трансекты (верхняя литораль), характеризующейся наименьшим периодом заливания.

На всей протяженности трансекты встречаются пыльцевые зерна более вытянутые или сплющенные, чем эталонная форма (1,4-3,2 \%). Достаточно редки пыльцевые зерна без содержимого (0,5-3\%). Такая пыльца практически не окрашивается кармином. Реже всего в пробах встречается смятая пыльца $(0,5-0,9 \%)$. Можно предположить, что данная пыльца была деформирована при проведении исследования, так как она хорошо окрашена кармином и имеет выраженную скульптуру экзины, что характерно для живых пыльцевых зерен.

Первая зона трансекты характеризуется самым коротким безводным периодом и не сильно выраженным приливно-отливным течением. В пробах пыльцы зафиксирован минимум нормально развитой пыльцы астры, но в максимальных количествах пустые (3,0\%), микроразмерные $(9,8 \%)$, гигантские $(0,7 \%)$ и смятые $(0,9 \%)$ пыльцевые зерна. Пыльца измененной формы $(1,9 \%)$ и без шипов экзины $(0,9 \%)$ представлена в среднем количестве.

Вторая зона трансекты характеризуется средним по времени безводным периодом и самым сильным приливно-отливным течением. Здесь обнаружено максимальное количество пыльцы астры солончаковой с нормальной морфологией $(89,7 \%)$. Все формы тератов встречаются в среднем количестве, кроме пыльцы с измененной формой (максимум - 3,2 \%).

Третья зона располагается ближе всего к береговой линии и для нее характерны небольшие глубины, самый длительный безводный период, лучшая освещенность и прогрев. В пробах пыльцы данной зоны зафиксировано среднее количество нормально развитой пыльцы $(86,6 \%)$. Максимально присутствие гигантской пыльцы $(1,2 \%)$ и пыльцы без шипов на экзине $(5,4 \%)$. В минимальных количествах присутствует пыльца с измененной формой $(1,4 \%)$ и пустая $(0,5 \%)$. Остальные формы тератов представлены в средних значениях.

Несмотря на отсутствие вблизи исследованной территории промышленных предприятий и стоков количество дефектных пыльцевых зерен астры солончаковой на протяженности трансекты колеблется в пределах 10,3-17,3\%. Величина коэффициента вариации $(\mathrm{CV})$ нормально развитой пыльцы у астры солончаковой в пределах трансекты составила $1,0-7,0 \%$, что свидетельствует о слабом варьировании этого признака и хорошей 
адаптированности генеративной сферы вида к условиям приливно-отливной зоны, что обеспечивает устойчивое половое воспроизведение.

Многочисленные исследования покали, что если в пыльниках формируется количество дефектной пыльцы 11 и менее процентов, то условия обитания растения вполне благоприятны для устойчивого генеративного размножения и формирования достаточного количества семян [2, 3]. Следовательно, наиболее комфортные условия обитания на трансекте, а значит и уровень адаптированности, что обеспечивает более устойчивое генеративное возобновление сформировались для астры солончаковой на второй зоне трансекты.

$$
* * *
$$

1. Елькина Н. А., Карпова Е.Е. Применение палиноиндикационного метода для оценки адаптивного потенциала приморских растений // Ученые записки ПетрГУ. Петрозаводск: Изд-во ПетрГУ, 2015. С. 52-56.

2. Круглова Н.Н. Критические фазы развития спорогенной клетки пыльника: к постановке проблемы // Цитология. 2001. Т. 43, № 3. С. 86, 87.

3. Куприянов П.Г. Соотносительная роль факторов, вызывающих появление дефектных пыльцевых зерен у растений в природе. Саратов: Изд-во Сарат. ун-та, 1983. 133 с.

4. Марковская Е.Ф., Сергиенко Л.А., Шкляревич Г.А., Сонина А.В., СтародубцеваА.А., Смолькова О.В. Природный комплекс побережий Белого моря. Петрозаводск: Изд-во КарНц РАН, 2010. 84c.

5. Паушева 3. П. Практикум по цитологии растений.- М.: Агропромиздат.- 1980.- 304 с.

6. Сонина А. В., Елькина Н. А., Марковская Е. Ф. Оценка состояния пыльцевых зерен растений приливноотливной зоны побережья Белого моря // Ученые записки ПетрГУ. Петрозаводск: Изд-во ПетрГУ, 2013. С. 7 11.

7. Punt W., Hoen P.P. Asteraceae - Asteroideae. The Northwest European Pollen Flora. Review of Palaeobotany and Palynology, 2009. Vol. 10. P. 22-183.

Ершова Е.С. ${ }^{1}$, Жесткова Е.М. ${ }^{2}$, Вейко Н.Н. ${ }^{1}$, Агафонова О.Н. ${ }^{1}$, Малиновская Е.М. ${ }^{1}$, Костюк С.В. ${ }^{1}$

Снижение количества повтора сателлита III (1q12) в составе ДНК плазмы периферической крови больных шизофренией

${ }^{1}$ ФГБНУ «Медико-генетический научный иентр имени академика Н.П. Бочкова»

${ }^{2}$ ГБУ «Психиатрическая клиническая больница № 4 им. П.Б. Ганнушкина» Департамента здравоохранения города Москвы

(Россия, Москва)

doi: 10.18411/trnio-10-2021-106

\section{Аннотация}

Шизофрения - тяжелое психическое заболевание, которое часто приводит к инвалидности. В последние годы ведется поиск биохимических и генетических маркеров этой патологии. Изменение содержания различных последовательностей в составе внеклеточной ДНК (вкДНК) может быть одним из таких маркеров. Была исследована выборка из популяции города Москвы (мужчины и женщины) с диагнозом - шизофрения (F20.00): пациенты в возрасте от 19 до 51 года с первым эпизодом психотического расстройства $(\mathrm{N}=147)$ и группа контроля $(\mathrm{N}=95)$ - психически и соматически здоровые лица в возрасте от 19 до 58 лет. Методом нерадиоактивной количественной гибридизации исследована ДНК плазмы и ДНК лейкоцитов крови пациентов. Показано, что в составе вкДНК больных значительно снижено содержание АТ-богатого тандемного повтора сателлита III из области 1q12 первой хромосомы.

Ключевые слова: шизофрения, сателлит III, копийность, внеклеточная ДНК.

\section{Abatract}

Schizophrenia is a severe mental illness that often results in disability. In recent years, there has been a search for biochemical and genetic markers of this pathology. Changes in the content of various sequences in the composition of extracellular DNA (cfDNA) may be one of these markers. Moscow city population sample was studied, men and women with a schizophrenia diagnosis (F20.00): patients with the first episode of psychotic disorder aged 19-51 years $(\mathrm{N}=147)$; and the 